\title{
Mitral and aortic valve surgery during left ventricular assist device implantation
}

\author{
Benjamin Smood, MD, Jason J. Han, MD, Mark Helmers, MD, and Pavan Atluri, MD
}

Feature Editor Note-As surgeons, it is necessary to know not only how to fix a problem, but as importantly, when to fix it. Sometimes less is more; at the same time, not addressing a surgical lesion may decrease the quantity and quality of the patient's life. These decisions pervade our practice in cardiac surgery, whether on the basis of dogma, observation, or systematic research.

The development of durable mechanical circulatory support represents a huge step forward in the treatment of advanced heart failure. Continued design improvements have expanded the pool of eligible patients as well as their survival. While this technology extends life, it also allows for progression of other disease processes. Heart failure surgeons face this predicament during implant: fix what is broken, let the pump fix it, fix everything every time, or never fix anything. The lack of unbiased data has made this an area of ongoing controversy.

In this Invited Expert Opinion, the authors explore the management of aortic and mitral valvulopathy in patients with left ventricular assist devices. They review current practices and surgical techniques and delineate a reproducible approach to this pathology. Sometimes, the enemy of good is better. And other times, an ounce of prevention is worth a pound of cure.

\section{Maureen E. Cheung, DO, and Nahush A. Mokadam, MD}

Mechanical circulatory support has been established as an alternative strategy for treating patients with end-stage heart failure. In select evaluations, survival after left ventricular assist device (LVAD) implantation approaches that of cardiac transplantation. ${ }^{1}$ Still, progress in the field rests not only on innovations in device engineering but also on further optimization of clinical management strategies.

In this respect, valvular dysfunction remains a challenging aspect of caring for patients with LVADs, and concomitant valvular surgery during LVAD implantation should only be undertaken by advanced programs and surgeons with experience in this area. Although there are

From the Division of Cardiovascular Surgery, Department of Surgery, University of Pennsylvania, Philadelphia, Pa.

Received for publication Nov 3, 2020; revisions received Dec 23, 2020; accepted for publication Jan 7, 2021; available ahead of print March 18, 2021.

Address for reprints: Pavan Atluri, MD, Division of Cardiovascular Surgery, University of Pennsylvania, 3400 Spruce St, 6 Silverstein Pavilion, Philadelphia, PA 19072 (E-mail: Pavan.Atluri@uphs.upenn.edu).

J Thorac Cardiovasc Surg 2022;164:970-7

$0022-5223 / \$ 36.00$

Copyright (c) 2021 by The American Association for Thoracic Surgery

https://doi.org/10.1016/j.jtcvs.2021.01.144

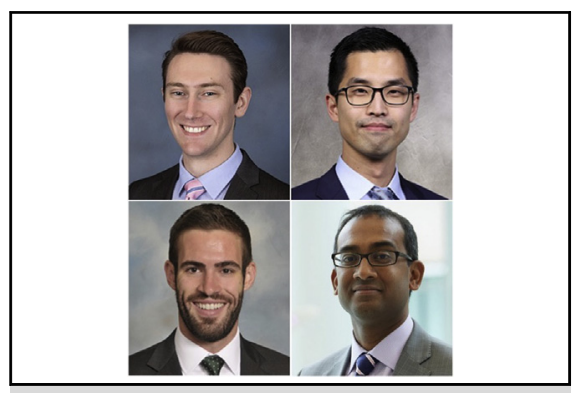

Top: Benjamin Smood (left) and Jason Han. Bottom: Mark Helmers (left) and Pavan Atluri.

CENTRAL MESSAGE

Evolving evidence suggests that indications for mitral or aortic valve surgery during LVAD implantation may be expanding in select patients with mitral regurgitation or aortic insufficiency.

See Commentaries on pages 978 and 979. some generally accepted indications for valvular surgery in patients requiring mechanical circulatory support (Table 1), there is a lack of consensus on if, when, and/or how one should surgically address mitral regurgitation (MR) and aortic insufficiency (AI) at the time of LVAD implantation. ${ }^{2,3}$ In the absence of clear guidelines, we summarize evolving evidence and offer our recommendations for approaching mitral valve (MV) and aortic valve (AV) surgery during LVAD implantation.

\section{PATHOPHYSIOLOGY AND NATURAL HISTORY OF UNCORRECTED VALVULAR DYSFUNCTION IN PATIENTS SUPPORTED WITH LVADS Mitral Regurgitation}

Although clinically significant (ie, moderate or worse) functional MR is a frequent manifestation and important prognosticator of outcomes among patients with end-stage heart failure, MR typically improves after LVAD implantation. ${ }^{4-6}$ For example, in a recent analysis of patients enrolled in the MOMENTUM 3 trial, although significant MR was present in nearly one half of patients before LVAD implantation, it persisted in just $\sim 5 \%$ to $15 \%$ at 1 month after surgery and rarely progressed at 2 years of follow-up. ${ }^{6}$

In large part, this is because LVADs decompress the left ventricle, which improves MV geometry and leaflet 
TABLE 1. Selected recommendations for mitral and aortic valve interventions during left ventricular assist device (LVAD) implantation

\begin{tabular}{|c|c|c|}
\hline Recommendations & COR & LOE \\
\hline \multicolumn{3}{|l|}{ General } \\
\hline $\begin{array}{l}\text { Treatment of coexisting valvular pathologies at the time of LVAD implant must be balanced against the anticipated duration of } \\
\text { support. }\end{array}$ & I & B \\
\hline \multicolumn{3}{|l|}{ Recommendations for mitral valve } \\
\hline $\begin{array}{l}\text { Severe mitral insufficiency is not a contraindication to mechanical circulatory support and does not routinely require surgical } \\
\text { repair or valve replacement, unless there is expectation of ventricular recovery. }\end{array}$ & IIb & $\mathrm{C}$ \\
\hline Routine mitral valve repair or replacement for severe mitral regurgitation is not recommended. & III & $\mathrm{C}$ \\
\hline \multicolumn{3}{|l|}{ Recommendations for mechanical mitral valves } \\
\hline Routine replacement of properly functioning mechanical mitral valve is not recommended. & III & $\mathrm{C}$ \\
\hline \multicolumn{3}{|l|}{ Recommendations for aortic valve disease } \\
\hline Functioning bioprosthetic valves do not require removal or replacement at the time of implant. & I & $\mathrm{C}$ \\
\hline $\begin{array}{l}\text { A mechanical aortic valve prosthesis should either be replaced with a bioprosthesis or covered/closed with a patch at the time of } \\
\text { LVAD implant. }\end{array}$ & I & $\mathrm{C}$ \\
\hline \multicolumn{3}{|l|}{ Recommendations for aortic regurgitation } \\
\hline More than mild aortic insufficiency should prompt consideration for surgical intervention during device implantation. & I & $\mathrm{C}$ \\
\hline
\end{tabular}

coaptation almost immediately by reversing annular dilatation and leaflet restriction. In addition, continuous offloading of ventricular wall stress can facilitate reverse myocyte remodeling to promote a sustained reduction in MR. ${ }^{4,5,7}$ This may provide some explanation for why 2-year survival rates after LVAD implantation, which have been estimated at $\sim 70 \%$ to $80 \%$, appear unaffected by the presence and/ or severity of pre-existing MR. ${ }^{6,8}$

Still, it is evident that some patients will have significant MR that persists after LVAD implantation, and MR may even recur despite initial resolution. ${ }^{5,6,8-12}$ Although several studies have suggested that residual MR persisting after LVAD implantation does not adversely affect functional status, readmission rates, or survival, others have refuted these assertions and have associated worse outcomes with persistent pulmonary hypertension and right ventricular dysfunction., $5,6,12-15$ These discrepancies are likely multifactorial and represent the inherent challenges of drawing broad conclusions from investigations that have significant heterogeneity in patient populations, interdependent risk factors, and variable medical and surgical management strategies. However, recent investigations have provided important insight into these nuanced relationships. For example, although residual moderate-to-severe MR may be well-tolerated in patients with LVADs, its coexistence with right ventricular dysfunction appears to portend greater morbidity and mortality and reduces 5-year survival from $\sim 55 \%$ to $<20 \%{ }^{15}$

\section{Aortic Insufficiency}

In stark contrast to MR, significant (ie, moderate or worse) AI is relatively uncommon in end-stage heart failure, yet it often worsens after LVAD implantation. Whereas the prevalence of mild AI before LVAD implantation has been cited at $\sim 20 \%$ to $30 \%$, moderate or worse AI may be present in just $\sim 5 \%$ of patients at the time of referral for cardiac transplantation or mechanical circulatory support. ${ }^{4,7,13,16-20}$ Meanwhile, the proportion of patients with significant AI may increase to $\sim 20 \%$ to $50 \%$ within 1 to 2 years after LVAD implantation, which some evidence has suggested occurs irrespective of the existence of AI or its degree of severity before surgery. ${ }^{4,7,17-21}$

Among other contributing factors, this is because supravalvular outflow delivered from the LVAD elevates the transaortic valve pressure gradient, which increases resistance to AV opening and ejection from the left ventricle. This alters the biomechanics of the AV apparatus and can directly traumatize AV leaflets, leading to new and/or progressive AI after LVAD implantation. ${ }^{4,7,16}$ In addition, commissural leaflet fusion by limited $\mathrm{AV}$ opening can further restrict leaflet mobility, thereby resulting in de novo AI. Although these effects are exacerbated at greater flows and with full LVAD support, even partial support with lower flows can still contribute to the development and/or progression of valvular and ventricular dysfunction over time., ${ }^{4,16,21}$ Importantly, any degree of AI after LVAD implantation creates a short circulatory loop of retrograde flow through the $\mathrm{AV}$, such that the device must generate greater output to provide the same amount of systemic hemodynamic support.

With this perspective, it is not surprising that significant AI after LVAD implantation increases hospital readmission and mortality rates. For example, we observed that 2-year 
mortality increased from $\sim 10 \%$ to $>40 \%$ among patients with either no or mild AI compared with those with moderate $\mathrm{AI}$ at 6 months after LVAD implantation, respectively. ${ }^{22}$ Others have demonstrated that once significant AI develops, 5 -year survival may decline from $\sim 50 \%$ to $\sim 35 \% .{ }^{19}$ Even among patients surviving to 1 year after LVAD implantation, the presence of significant $\mathrm{AI}$ has been observed to reduce 2-year survival from $\sim 75 \%$ to $\sim 70 \%{ }^{19}$ Although other investigations have failed to consistently demonstrate significant associations between the presence/severity of AI after LVAD implantation and outcomes pertaining to quality of life and/or survival, ${ }^{20,21}$ these discrepancies may be partially due to the fact that, until recently, there was a relative paucity of large studies including patients with LVADs as destination therapy. ${ }^{18,19}$

In addition, important questions have recently been raised regarding whether even mild pre-existing $\mathrm{AI}$ at the time of LVAD implantation may contribute to progressive valvular dysfunction and adverse postoperative outcomes. Although current evidence is limited, significant AI may be more than twice as likely to develop in patients with mild preimplantation AI compared with those with none. ${ }^{17,19}$ For example, Tanaka and colleagues ${ }^{17}$ recently demonstrated that the incidence of moderate AI after LVAD implantation increases from $\sim 10 \%$ to almost $50 \%$ when comparing patients with none or trace preimplantation AI with those with only mild preimplantation AI, respectively. Although 2-year complication rates and survival were similar between the groups, patients with mild AI had significantly worse functional status and greater rates of hospital readmission at follow-up.

\section{SURGICAL APPROACHES AND OPERATIVE TECHNIQUES FOR ADDRESSING THE MVS AND AVs DURING LVAD IMPLANTATION MV Repair}

In an effort to maintain competency of the MV after LVAD implantation, both concomitant MV annuloplasty and edge-to-edge repair techniques at the time of LVAD implantation have been described. ${ }^{23}$ Concomitant MV annuloplasty is often completed using standard surgical principles and techniques for MV repair, including median sternotomy, cardiopulmonary bypass, cardioplegic arrest, and MV exposure through a left atriotomy or transseptal approach. However, some experienced surgeons will complete the operation under fibrillatory arrest when it is necessary to avoid aortic crossclamping and cardioplegic arrest. In any case, the MV is typically addressed after securing the apical sewing ring of the LVAD so that the ventriculotomy can be left open for venting during MV reconstruction.

Alternatively, MR can also be addressed during LVAD implantation with an edge-to-edge repair technique. With this approach, the MV leaflets are approximated with horizontal mattress sutures placed through the left ventriculotomy, or with a transaortic valve approach to the MV. It is important to note that following an edge-to-edge repair, assurance of large residual orifices is vital to ensuring adequate LVAD filling and to reduce the risk of MV stenosis. Some favor an edge-to-edge repair when trying to avoid prolonged cardiopulmonary bypass times, or when using less-invasive approaches for LVAD implantation (ie, via thoracotomy or subcostal incisions). ${ }^{23}$ However, an edge-toedge repair is not always appropriate, for example, when leaflets are severely fused and tethered, or in severe degenerative disease when there is excessive leaflet prolapse. We favor a standard transatrial rigid mitral annuloplasty technique for correction of MR, when addressed, given the durability of repair and limited risk of mitral stenosis.

\section{AV Replacement and Repair}

Because AI often worsens after LVAD implantation, concomitant AV intervention during LVAD implantation is quite common and most often consists of $\mathrm{AV}$ replacement with a bioprosthetic valve, or partial (ie, central) closure of the AV leaflets. ${ }^{18,24}$ Both typically require aortic crossclamping and prolonged cardioplegic arrest.

Although bioprosthetic AV replacement was longconsidered the preferred surgical intervention for addressing $\mathrm{AI}$ at the time of LVAD implantation, this approach has recently fallen out of favor with some surgeons. In part, this is due to concerns regarding the potential for accelerated bioprosthetic valve degeneration, thromboembolic complications, and other risks associated with longer operative and ischemic times when compared with partial AV closure. Despite these reservations, some surgeons, including our group, still prefer AV replacement, given the additive time required for an AV replacement is minimal, with enhanced durability and limited concern of leaflet tearing. This is particularly true in patients receiving an LVAD as destination therapy, who may be more likely to benefit from more immediate resolution of their AI, and/ or less likely to outlive their bioprosthetic valve. Were the bioprosthetic AV to degenerate with de novo AI, a valvein-valve transcatheter aortic valve replacement (TAVR) is rather straightforward with the bioprosthetic valve apparatus in place.

In an effort to avoid some of the risks associated with $\mathrm{AV}$ replacement, AI also has been treated effectively with partial closure of the AV leaflets using a Park's stitch or other similar techniques. ${ }^{24}$ With this approach, a purse-string suture is placed through each of the AV leaflets to maintain central coaptation while permitting some degree of $\mathrm{AV}$ opening, closing, and ejection from the ventricle. Of note, partial closure of the AV is often considered a lessdurable intervention than $\mathrm{AV}$ replacement, and some studies suggest that AI may recur in up to $20 \%$ of patients within just 6 months after LVAD implantation. ${ }^{18}$ 
TABLE 2. Key Investigations comparing outcomes of patients receiving concomitant MV procedures versus those who did not during LVAD implantation

\begin{tabular}{|c|c|c|c|c|c|c|c|c|c|}
\hline Study & $\begin{array}{c}\text { Study design } \\
\text { and details }\end{array}$ & $\begin{array}{c}\text { Number of } \\
\text { patients }\end{array}$ & CPB times & $\begin{array}{c}\text { Hospital } \\
\text { length } \\
\text { of stay }\end{array}$ & $\begin{array}{c}\text { Early } \\
\text { mortality }\end{array}$ & $\begin{array}{c}\text { Late } \\
\text { survival }\end{array}$ & $\begin{array}{c}\text { Freedom } \\
\text { from valvular } \\
\text { dysfunction }\end{array}$ & Other & Conclusions \\
\hline $\begin{array}{l}\text { Pawale } \\
\text { et al, } \\
2019^{23}\end{array}$ & $\begin{array}{l}\text { Retrospective, } \\
\text { cohort study. } \\
\text { Outcomes } \\
\text { after adopting } \\
\text { a systemic } \\
\text { approach to } \\
\text { repairing } \\
\text { severe MR } \\
\text { during LVAD } \\
\text { implantation } \\
\text { (2013-2017) } \\
\text { compared } \\
\text { with historical } \\
\text { controls } \\
\text { without MV } \\
\text { procedures } \\
\text { (2011-2013) }\end{array}$ & $\begin{array}{l}\text { MVP, } \\
\quad n=78 \\
\text { No MVP, } \\
n=28\end{array}$ & $\begin{array}{l}\text { Longer with } \\
\text { MVP } \\
\text { (142 min } \\
\text { vs } 97 \mathrm{~min})\end{array}$ & $\begin{array}{l}\text { Shorter with } \\
\text { MVPs } \\
(17 \mathrm{~d} \\
\text { vs } 22 \mathrm{~d})\end{array}$ & $\begin{array}{l}\text { Similar } \\
\quad(2.6 \% \\
\text { vs } 3.6 \%)\end{array}$ & $\begin{array}{c}\text { Similar 2-y } \\
\text { survival } \\
(90.2 \% \\
\text { vs } 79.7 \%)\end{array}$ & $\begin{array}{l}\text { Improved at } \\
3 \text { mo with } \\
\text { MVPs ( } 100 \% \\
\text { vs } 71 \% \text { ) }\end{array}$ & $\begin{array}{l}\text { Fewer } \\
\quad \text { readmissions } \\
\text { after MVPs } \\
(7.1 \% \text { vs } \\
19.7 \%)\end{array}$ & $\begin{array}{l}\text { MVPs are safe } \\
\text { and better at } \\
\text { reducing severity } \\
\text { of MR } \\
\text { MVPs reduce heart } \\
\text { failure readmission } \\
\text { rates }\end{array}$ \\
\hline $\begin{array}{l}\text { Sugiura } \\
\text { et al, } \\
2019^{13}\end{array}$ & $\begin{array}{l}\text { Retrospective, } \\
\text { single-center } \\
\text { analysis of } \\
\text { all patients } \\
\text { undergoing } \\
\text { concomitant } \\
\text { VPs during } \\
\text { LVAD } \\
\text { implantation }\end{array}$ & $\begin{array}{l}\text { Total } \\
\quad \text { VPs }=91, \\
\text { including } \\
\text { MVP, } \mathrm{n}=30 \\
\text { AVP, } \mathrm{n}=19 \\
\text { No VP, } \\
\quad \mathrm{n}=435\end{array}$ & $\begin{array}{l}\text { Longer } \\
\text { with MVP } \\
\quad(120 \mathrm{~min} \\
\text { vs } 78 \mathrm{~min})\end{array}$ & $\begin{array}{l}\text { Similar } \\
\qquad(48 \mathrm{~d} \\
\quad \text { vs } 41 \mathrm{~d})\end{array}$ & $\begin{array}{l}\text { Similar } \\
\qquad(11 \% \\
\text { vs } 10 \%)\end{array}$ & 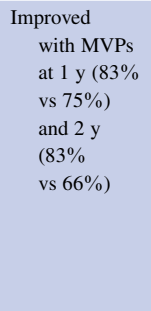 & - & $\begin{array}{l}\text { Greater right } \\
\text { heart failure } \\
\text { with VPs } \\
(29 \% \text { vs } 15 \%) \text {, } \\
\text { which may be } \\
\text { secondary to } \\
\text { prolonged CPB } \\
\text { times, } \\
\text { crossclamping, } \\
\text { and cardioplegic } \\
\text { arrest }\end{array}$ & $\begin{array}{l}\text { MVPs may have } \\
\text { more benefit in } \\
\text { patients with } \\
\text { severe MR } \\
\text { Decision to perform } \\
\text { concomitant VPs } \\
\text { should be based } \\
\text { on clinical } \\
\text { indications for } \\
\text { VPs }\end{array}$ \\
\hline $\begin{array}{l}\text { Choi } \\
\qquad \begin{array}{l}\text { et al. } \\
2018^{11}\end{array}\end{array}$ & $\begin{array}{l}\text { Systematic review, } \\
8 \text { studies } \\
\text { comparing } \\
\text { patients with } \\
\text { and without } \\
\text { MVPs during } \\
\text { LVAD } \\
\text { implantation }\end{array}$ & $\begin{array}{l}\text { MVPs, } \\
\quad n=113 \\
\text { No MVP, } \\
n=332\end{array}$ & $\begin{array}{l}\text { Similar } \\
\qquad(154 \mathrm{~min} \\
\quad \text { vs } 119 \mathrm{~min})\end{array}$ & $\begin{array}{l}\text { Similar } \\
\qquad(21 \mathrm{~d} \\
\text { vs } 18 \mathrm{~d})\end{array}$ & - & $\begin{array}{l}\text { Similar 6-mo } \\
\quad \text { survival } \\
\quad(77 \% \\
\text { vs } 81 \%) \\
\text { Similar } 1-y \\
\text { survival } \\
(72 \% \\
\text { vs } 80 \%)\end{array}$ & $\begin{array}{l}\text { Similar } \\
\qquad(100 \% \\
\text { vs } 74 \%)\end{array}$ & - & $\begin{array}{l}\text { MVPs are safe and } \\
\text { have comparable } \\
\text { survival with } \\
\text { LVAD implantation } \\
\text { alone but may } \\
\text { not be required }\end{array}$ \\
\hline $\begin{array}{c}\text { Robertson } \\
\text { et al, } \\
2018^{9}\end{array}$ & $\begin{array}{l}\text { Retrospective, } \\
\text { INTERMACS } \\
\text { database }\end{array}$ & $\begin{array}{l}\text { MV repair, } \\
\quad n=252 \\
\text { MV } \\
\quad \text { replacement, } \\
n=11 \\
\text { No MVP, } \\
n=4667\end{array}$ & $\begin{array}{l}\text { Longer } \\
\text { with MVP } \\
\text { (117 min } \\
\text { vs } 93 \mathrm{~min})\end{array}$ & $\begin{array}{l}\text { Longer } \\
\text { with MVP } \\
\qquad \begin{array}{l}(27 \mathrm{~d} \\
\text { vs } 26 \mathrm{~d})\end{array}\end{array}$ & $\begin{array}{l}\text { Similar } \\
\qquad \begin{array}{l}(5 \% \text { vs } \\
0 \%-5 \%)\end{array}\end{array}$ & $\begin{array}{l}\text { Similar } 2- \\
\text { ysurvival } \\
(71 \% \text { vs } \\
57 \%-76 \%) \\
\text { Trend toward } \\
\text { improved } \\
\text { 2-y survival } \\
\text { with MV } \\
\text { procedures } \\
\text { among } \\
\text { patients with } \\
\text { LVADs as } \\
\text { destination } \\
\text { therapy } \\
(73 \% \text { vs } \\
64 \%)\end{array}$ & $\begin{array}{l}\text { Similar at } \\
3 \text { mo }(18 \% \\
\text { vs } 25 \%)\end{array}$ & $\begin{array}{l}\text { Improved } 1-y \\
\text { quality of life } \\
\text { with MVP } \\
\text { Fewer readmissions } \\
\text { with MVP at } \\
1 \text { y (32\% vs } \\
23 \%) \text { and } 2 \text { y } \\
(17 \% \text { vs } 10 \%)\end{array}$ & $\begin{array}{l}\text { Concomitant MV } \\
\text { procedures may } \\
\text { reduce } \\
\text { readmissions, } \\
\text { improve quality } \\
\text { of life, and offer } \\
\text { long-term survival } \\
\text { when destination } \\
\text { therapy is } \\
\text { anticipated }\end{array}$ \\
\hline $\begin{array}{l}\text { Fukuhara } \\
\text { et al, } \\
2017^{25}\end{array}$ & $\begin{array}{l}\text { Retrospective, } \\
\text { single-center }\end{array}$ & $\begin{array}{l}\text { MVP, } n=52 \\
\text { No MVP, } \\
\quad n=63\end{array}$ & $\begin{array}{l}\text { Longer with } \\
\text { MVP } \\
\text { (125 min } \\
\text { vs } 89 \mathrm{~min}) \\
\text { Similar among } \\
\text { MV ring } \\
\text { annuloplasty } \\
\text { vs edge-to- } \\
\text { edge repair } \\
\text { (121 min } \\
\text { vs } 103 \mathrm{~min} \text { ) }\end{array}$ & $\begin{array}{l}\text { Similar } \\
\qquad(41 \mathrm{~d} \\
\text { vs } 34 \mathrm{~d})\end{array}$ & $\begin{array}{l}\text { Similar } 30-\mathrm{d} \\
\text { mortality } \\
(4 \% \text { vs } 0 \%) \\
\text { Similar } \\
\quad \text { hospital } \\
\text { mortality } \\
(11.5 \% \\
\text { vs } 3.2 \%)\end{array}$ & $\begin{array}{l}\text { Similar at } \\
2 \text { y }(79 \% \\
\text { vs } 86 \%)\end{array}$ & $\begin{array}{l}\text { Improved at } \\
1 \text { y after } \\
\text { MVP }(35 \% \\
\text { vs } 10 \%)\end{array}$ & $\begin{array}{l}\text { Less right heart } \\
\text { failure among } \\
\text { patients with } \\
\text { MVPs }(13.6 \% \\
\text { vs } 2.2 \%)\end{array}$ & $\begin{array}{l}\text { MVPs are associated } \\
\text { with less right } \\
\text { heart failure, } \\
\text { which challenges } \\
\text { the notions that } \\
\text { concurrent MV } \\
\text { procedures are } \\
\text { not warranted }\end{array}$ \\
\hline
\end{tabular}


TABLE 2. Continued

\begin{tabular}{|c|c|c|c|c|c|c|c|c|c|}
\hline Study & $\begin{array}{l}\text { Study design } \\
\text { and details }\end{array}$ & $\begin{array}{c}\text { Number of } \\
\text { patients }\end{array}$ & CPB times & $\begin{array}{l}\text { Hospital } \\
\text { length } \\
\text { of stay }\end{array}$ & $\begin{array}{c}\text { Early } \\
\text { mortality }\end{array}$ & $\begin{array}{c}\text { Late } \\
\text { survival }\end{array}$ & $\begin{array}{c}\text { Freedom } \\
\text { from valvular } \\
\text { dysfunction }\end{array}$ & Other & Conclusions \\
\hline $\begin{array}{l}\text { Tanaka } \\
\text { et al, } \\
2017^{14}\end{array}$ & $\begin{array}{l}\text { Retrospective, } \\
\text { single-center } \\
\text { analysis of } \\
\text { patients without } \\
\text { significant MR } \\
\text { after LVAD } \\
\text { implantation, } \\
\text { and comparing } \\
\text { those who had } \\
\text { MVPs with } \\
\text { those with } \\
\text { spontaneous } \\
\text { resolution of } \\
\text { MR }\end{array}$ & $\begin{array}{l}\text { MR improved } \\
\text { with MVP, } \\
\mathrm{n}=56 \\
\text { Spontaneously } \\
\text { improvement } \\
\text { in MR } \\
\text { without } \\
\text { MVP, } \mathrm{n}=54\end{array}$ & $\begin{array}{l}\text { Longer with } \\
\text { MVP } \\
\text { (177 min vs } \\
123 \mathrm{~min})\end{array}$ & $\begin{array}{l}\text { Similar } \\
\qquad(20 \mathrm{~d} \\
\text { vs } 18 \mathrm{~d})\end{array}$ & $\begin{array}{l}\text { Lower hospital } \\
\text { mortality } \\
\text { with MVP } \\
(11 \% \text { vs } \\
19 \%)\end{array}$ & $\begin{array}{l}\text { Improved at } \\
1 \text { y with } \\
\text { MVP }(70 \% \\
\text { vs } 59 \%)\end{array}$ & $\begin{array}{l}\text { Improved at } \\
1 \text { y with } \\
\text { MVP }(95 \% \\
\text { vs } 76 \%)\end{array}$ & $\begin{array}{l}\text { Greater improvement } \\
\text { in pulmonary } \\
\text { vascular resistance } \\
\text { with MVP (2.0 } \\
\text { Wood units vs } \\
1.7 \text { Wood units) } \\
\text { Improved pulmonary } \\
\text { wedge pressure } \\
\text { with MVP } \\
\text { (12 } \mathrm{mm} \mathrm{Hg} \\
\text { vs } 17 \mathrm{~mm} \mathrm{Hg})\end{array}$ & $\begin{array}{l}\text { MV procedures } \\
\text { improve mid-term } \\
\text { hemodynamics } \\
\text { and survival } \\
\text { compared with } \\
\text { spontaneously } \\
\text { improved MR } \\
\text { More aggressive } \\
\text { intervention on } \\
\text { the MV during } \\
\text { LVAD implantation } \\
\text { may be warranted }\end{array}$ \\
\hline $\begin{array}{l}\text { Taghavi } \\
\text { et al, } \\
2013^{10}\end{array}$ & $\begin{array}{l}\text { Multicenter, } \\
\text { retrospective } \\
\text { study } \\
\text { (4 centers })\end{array}$ & $\begin{array}{l}\text { MVP, } n=21 \\
\text { No MVP, } \\
\quad n=36\end{array}$ & $\begin{array}{l}\text { Longer with } \\
\text { MVP } \\
\text { (154 min } \\
\text { vs } 109 \mathrm{~min})\end{array}$ & $\begin{array}{l}\text { Similar } \\
\qquad(32 \mathrm{~d} \\
\quad \text { vs } 43 \mathrm{~d})\end{array}$ & $\begin{array}{l}\text { Similar at } \\
\quad \text { 3-mo } \\
\text { survival } \\
\quad(10 \% \\
\quad \text { vs } 17 \%)\end{array}$ & $\begin{array}{l}\text { Similar at } 1 \mathrm{y} \\
\quad(84 \% \text { vs } 67 \%)\end{array}$ & - & $\begin{array}{l}\text { Greater reduction } \\
\text { in PVR with MVP } \\
(59 \% \text { vs } 35 \%)\end{array}$ & $\begin{array}{l}\text { MVPs have greater } \\
\text { reduction on PVR, } \\
\text { which may permit } \\
\text { some patients to } \\
\text { become candidates } \\
\text { for transplant }\end{array}$ \\
\hline
\end{tabular}

$C P B$, Cardiopulmonary bypass; $M R$, mitral regurgitation; $L V A D$, left ventricular assist device; $M V$, mitral valve; $M V P$, mitral valve procedure; $V P$, valve procedure; $A V P$, aortic valve procedure; $A V$, aortic valve; INTERMACS, Interagency Registry for Mechanically Assisted Circulatory Support.

Meanwhile, complete closure of the AV with oversewing or patch implantation has also been described with some success. However, this technique has perhaps the worst outcomes after LVAD implantation compared with other AV interventions $^{18}$ and is now generally avoided. ${ }^{3}$ This is particularly true in patients who are expected to be weaned from LVAD support, which would require AV reintervention at the eventual time of LVAD explant. Moreover, complete closure of the AV prohibits antegrade intracardiac blood flow, which can impair myocardial recovery, or risk precipitous circulatory collapse if the LVAD suddenly ceased to function or required a temporary reduction of flows, such as during circuit exchaanges. ${ }^{7}$ Traditional AV ring annuloplasty has also been described at the time of LVAD implantation, but these studies are limited and remain exploratory in the LVAD population.

\section{SURGICAL OUTCOMES AFTER CONCOMITANT MV OR AV SURGERY DURING LVAD IMPLANTATION \\ Outcomes After MV Interventions}

Numerous studies have sought to elucidate the impact of concomitant MV interventions during LVAD implantation on postoperative outcomes (Table 2). ${ }^{9-11,13,14,23,25}$ However, the results have been rather unremarkable to date and have demonstrated only marginal functional and hemodynamic benefits in select patient populations, which have yet to reliably translate into any meaningful difference in survival among broader populations of LVAD recipients. ${ }^{9-11,25}$

Nevertheless, some still advocate for an aggressive approach to MV intervention at the time of LVAD implantation, particularly in cases of destination therapy in which patients might have fewer options for treating significant MR should it persist postoperatively. ${ }^{9,14,23}$ In some cases, the results have been reassuring and have demonstrated lower rates of right heart failure and improved survival compared with MR that resolves spontaneously after LVAD implantation. ${ }^{14,25}$ Even when survival has not improved with destination therapy, some evidence suggests that concomitant MV procedures during LVAD implantation decrease hospi-

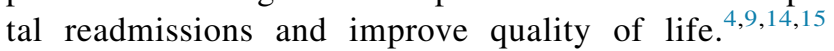
Furthermore, some recent evidence suggests that concomitant MV surgery should be carefully considered in other select patient populations, such as when LVAD support is expected to exceed 1 year, or in patients with severe pulmonary hypertension and/or right ventricular dysfunction. ${ }^{9,14,15,25}$

\section{Outcomes After AV Interventions}

Although earlier studies suggested that AV interventions during LVAD implantation might adversely impact survival, more recent evidence makes it apparent that $\mathrm{AV}$ interventions during LVAD implantation tend to improve patient outcomes, particularly when there is moderate-to-severe AI before LVAD implantation (Table 3). ${ }^{2-4,7,14,18,24,26,27}$ However, despite the fact that there is growing evidence to suggest that even mild preimplantation $\mathrm{AI}$ is associated with poor postoperative hemodynamics, which may compound right ventricular dysfunction and ultimately patient outcomes, global consensus remains lacking on the role for concomitant AV interventions in patients with only mild preimplantation AI. ${ }^{2,3,17,19,27}$ 
TABLE 3. Key investigations comparing outcomes of patients receiving concomitant AVPs versus those who did not during LVAD implantation

\begin{tabular}{|c|c|c|c|c|c|c|c|c|}
\hline Source & $\begin{array}{c}\text { Study design } \\
\text { and details }\end{array}$ & $\begin{array}{c}\text { Number of } \\
\text { patients }\end{array}$ & CPB times & $\begin{array}{l}\text { Hospital } \\
\text { length } \\
\text { of stay }\end{array}$ & $\begin{array}{c}\text { Early } \\
\text { mortality }\end{array}$ & Late survival & $\begin{array}{l}\text { Freedom from } \\
\text { valvular } \\
\text { dysfunction }\end{array}$ & Conclusions \\
\hline $\begin{array}{l}\text { Fukuhura } \\
\quad \text { et al, } 2017^{27}\end{array}$ & $\begin{array}{l}\text { Retrospective, } \\
\text { single-center } \\
\text { comparison } \\
\text { of AVP on } \\
\text { patients with } \\
\text { mild pre- } \\
\text { existing AI }\end{array}$ & $\begin{array}{c}\text { AVP, } \\
n=41 \\
\text { No AVP, } \\
n=15\end{array}$ & $\begin{array}{l}\text { Similar } \\
\quad(112 \mathrm{~min} \\
\quad \text { vs } 92 \mathrm{~min})\end{array}$ & - & - & $\begin{array}{c}\text { Similar 2-y survival } \\
\quad(63 \% \text { vs } 84 \%)\end{array}$ & $\begin{array}{l}\text { Improved at } 2 \mathrm{y} \\
\text { with AVP ( } 82 \% \\
\text { vs } 45 \%) \\
\text { More AI in patients } \\
\text { with large BSA } \\
\text { ( }>75 \text { th percentile) }\end{array}$ & $\begin{array}{l}\text { Progression of AI } \\
\text { with mild } \\
\text { preimplantation } \\
\text { AI is highly } \\
\text { prevalent, but is } \\
\text { much lower when } \\
\text { AVPs are } \\
\text { performed } \\
\text { Baseline aortic } \\
\text { diameter may } \\
\text { help identify } \\
\text { patients needing } \\
\text { AV procedures at } \\
\text { the time of LVAD } \\
\text { implantation }\end{array}$ \\
\hline $\begin{array}{l}\text { Robertson } \\
\quad \text { et al, } 2015^{18}\end{array}$ & $\begin{array}{l}\text { Retrospective, } \\
\text { INTERMACS } \\
\text { database }\end{array}$ & $\begin{array}{l}\text { AV repair, } \\
\quad \text { including } \\
\text { partial } \\
\text { closure, } \\
\mathrm{n}=95 \\
\mathrm{AV} \\
\quad \text { replacement, } \\
\mathrm{n}=85 \\
\mathrm{AV} \text { complete } \\
\text { closure, } \\
\mathrm{n}=125 \\
\text { No AVP, } \\
\mathrm{n}=5039\end{array}$ & $\begin{array}{l}\text { Shorter without } \\
\text { AVP (91 min), } \\
\text { specifically } \\
\text { longer with } \\
\text { AV } \\
\text { replacement } \\
\text { (162 min) } \\
\text { compared } \\
\text { with other } \\
\text { AVPs }\end{array}$ & $\begin{array}{l}\text { Shorter without } \\
\text { AVP }(24 \text { d), } \\
\text { specifically } \\
\text { longer with } \\
\text { AV repair } \\
\text { (36 d) compared } \\
\text { with other AVPs }\end{array}$ & $\begin{array}{l}\text { Highest at } \\
3 \text { mo with } \\
\text { complete } \\
\text { AV closure }\end{array}$ & $\begin{array}{l}\text { Worse at } 1 \text {-y with } \\
\text { complete AV closure } \\
(64 \%) \text { compared } \\
\text { with repair }(79 \%) \text { or } \\
\text { replacement }(72 \%) \text {, } \\
\text { or no AVP }(81 \%)\end{array}$ & $\begin{array}{l}\text { Worse at } 6 \text { mo with } \\
\text { AV repair }(19 \%) \\
\text { compared with } \\
\text { AV replacement } \\
(9 \%) \text {, complete } \\
\text { AV closure }(6 \%), \\
\text { or no AVP }(10 \%)\end{array}$ & $\begin{array}{l}\text { Complete AV closure } \\
\text { significantly } \\
\text { increases } \\
\text { mortality, and } \\
\text { should be avoided, } \\
\text { particularly in } \\
\text { INTERMACS } \\
\text { level } 1-2 \text { patients } \\
\text { Survival with AV } \\
\text { repair is } \\
\text { comparable } \\
\text { with survival } \\
\text { without AVPs } \\
\text { AV repair is limited } \\
\text { by greater } \\
\text { postoperative } \\
\text { AI }\end{array}$ \\
\hline $\begin{array}{l}\text { John et al } \\
2014^{26}\end{array}$ & $\begin{array}{l}\text { Retrospective } \\
\text { review of } \\
\text { HeartMate II } \\
\text { bridge-to- } \\
\text { transplantation } \\
\text { or Destination } \\
\text { Therapy } \\
\text { clinical trial }\end{array}$ & $\begin{array}{l}\text { Total } \\
\quad \text { concomitant } \\
\text { VPs, } \mathrm{n}=281, \\
\text { including: } \\
\text { AVP, } \mathrm{n}=80 \\
\text { MVP, } \mathrm{n}=45 \\
\text { No VP, } \\
\mathrm{n}=641\end{array}$ & $\begin{array}{l}\text { Longer with VPs } \\
\qquad(137 \mathrm{~min} \\
\text { vs } 93 \mathrm{~min})\end{array}$ & $\begin{array}{l}\text { Longer with } \\
\text { VPs ( } 35 \mathrm{~d} \\
\text { vs } 31 \mathrm{~d})\end{array}$ & $\begin{array}{c}\text { Greater } 30-\mathrm{d} \\
\text { mortality } \\
\text { with any } \\
\text { VP }(10.3 \% \\
\text { vs } 4.8 \%) \\
\text { Trend toward } \\
\text { greater } \\
\text { mortality } \\
\text { with AVP } \\
(10.9 \%) \\
\text { and MVP } \\
(11.5 \%)\end{array}$ & $\begin{array}{r}\text { Lower with AVP at } 1 \mathrm{y} \\
(75 \% \text { vs } 57 \% \text { ) and } \\
2 \mathrm{y}(64 \% \text { vs } 43 \%)\end{array}$ & - & $\begin{array}{l}\text { Underlying cardiac } \\
\text { sequelae of } \\
\text { valvular heart } \\
\text { disease may be } \\
\text { responsible for } \\
\text { added risks in } \\
\text { patients } \\
\text { undergoing VPs, } \\
\text { rather than the } \\
\text { procedures } \\
\text { themselves }\end{array}$ \\
\hline
\end{tabular}

$C P B$, Cardiopulmonary bypass; $A V P$, aortic valve procedure; $A I$, aortic insufficiency; $B S A$, body surface area; $A V$, aortic valve; $L V A D$, left ventricular assist device; $I N T E R M A C S$, Interagency Registry for Mechanically Assisted Circulatory Support; $V P$, valve procedure; $M V P$, mitral valve procedure.

\section{RECOMMENDATIONS FOR MVAND AV SURGERY IN PATIENTS WITH LVADS}

\section{Addressing MR at the Time of LVAD Implantation}

In our practice, we only address the MV at the time of LVAD implantation in patients with significant MR when we anticipate they will recover to LVAD explant. In this respect, we agree with current mechanical circulatory support guideline recommendations that even severe MR does not routinely warrant MV intervention unless ventricular recovery is expected (Table 1). ${ }^{2,3}$ However, it is worth highlighting that current guidelines do not indicate whether MV interventions should be performed prophylactically during LVAD implantation, or at the time of explant, nor do they indicate which specific operative techniques are preferred. Because there are no randomized controlled trials to help determine the best way to manage this unique patient population, these ambiguities are somewhat expected.

Nevertheless, in recognizing these limitations, growing evidence now suggests that concomitant MV interventions at the time of LVAD implantation durably improve MR and meaningfully reduce pulmonary vascular resistance as well as the risk of long-term right heart failure, specifically in patients in whom early myocardial recovery and LVAD explant are expected. 2,9,10,14,15,23,25 Thus, for this select population, we recommend that MV interventions be performed at the time of LVAD implantation, rather than waiting until explant. Moreover, because we find that the MV can typically be repaired in an expeditious fashion, and because the long-term durability of edge-to-edge repairs remains uncertain (Table 2), we recommend using standard cardioplegic arrest to repair the MV with a true-sized 
annuloplasty ring via a left atriotomy at the time of LVAD implantation.

If adequate repair cannot be achieved with annuloplasty, either bioprosthetic MV replacement or an edge-to-edge repair at the time of LVAD implantation should be considered for patients expected to recover to explant. Of note, even though there are limited reports of successful percutaneous MV repair (ie, MitraClip) in patients with LVADs, further investigations are needed before this practice should be considered as routine therapy in broader populations of patients with LVADs.

\section{Addressing AI at the Time of LVAD Implantation}

In our experience, patient outcomes are demonstrably worse when significant AI develops after LVAD implantation. $^{22}$ Meanwhile, the natural history of AI after LVAD implantation is well-described, and growing evidence suggests that even mild pre-existing $\mathrm{AI}$ is likely to progress after LVAD implantation in the absence of AV intervention. ${ }^{17,19,27}$ Therefore, we take a more aggressive approach to addressing the $\mathrm{AV}$ at the time of LVAD implantation compared with current mechanical circulatory support guideline recommendations (Table 1$).^{2,3}$ In our practice, all patients with mild or worse AI undergo either bioprosthetic AV replacement or AV repair with a Park's stitch at the time of LVAD implantation. Despite some reservations by others, we recommend replacing the AV whenever possible, as we find that it does not significantly increase ischemic and cardiopulmonary bypass times, and likely provides a more durable solution compared to partial AV closure (Table 3). ${ }^{18,26,27}$

As noted previously, if bioprosthetic valve degeneration occurs after concomitant AV replacement during LVAD implantation, we recommend that serious consideration be given to valve-in-valve TAVR. In contrast, although there have been some successful reports describing the use of TAVR as an initial AV-replacement strategy in patients with LVADs, the use of rapid deployment valves to treat native valve AI remains investigational, with mixed results. In our experience, currently available TAVR models are challenging to seat and do not reliably achieve a good seal in patients with LVAD and AI, even when upsizing the valve by $30 \%$, and will often require more than 1 transcatheter valve. As such, we do not recommend the routine use of TAVR as a strategy for managing native AI in patients after LVAD implantation.

In addition, although a recent anecdote has noted patients with LVADs can be safely managed with mechanical valves at low flows, this approach remains unsupported. Traditional teaching has been that mechanical AVs are contraindicated in patients with LVADs for fear of thrombus formation on the valve, and we agree with current guideline recommendations that consideration should still be given to either bioprosthetic valve re-replacement or closure of previous mechanical $\mathrm{AV}$ replacements at the time of LVAD implantation (Table 1).

\section{CONCLUSIONS}

Evolving evidence suggests that carefully selected patients may benefit from concomitant MV or AV interventions at time of LVAD implantation. Although future investigations may prove that there is a role for concomitant MV surgery in patients with significant MR who receive LVADs as destination therapy and/or those with coexisting right ventricular dysfunction, we currently recommend that significant MR only be addressed at the time of LVAD implantation among patients who are expected to recover to LVAD explant. Meanwhile, we favor a more aggressive approach to addressing the AV during LVAD implantation and suggest that future guideline recommendations seriously consider expanding the indications for concomitant AV interventions during LVAD implantation to include patients with even mild preimplantation AI.

\section{Conflict of Interest Statement}

The authors reported no conflicts of interest.

The Journal policy requires editors and reviewers to disclose conflicts of interest and to decline handling or reviewing manuscripts for which they may have a conflict of interest. The editors and reviewers of this article have no conflicts of interest.

\section{References}

1. Mehra MR, Uriel N, Naka Y, Cleveland JC, Yuzefpolskaya M, Salerno CT, et al; MOMENTUM 3 Investigators. A fully magnetically levitated left ventricular assist device-final report. N Engl J Med. 2019;380:1618-27.

2. Feldman D, Pamboukian SV, Teuteberg JJ, Birks M, Lietz K, Moore SA, et al. The 2013 International Society for Heart and Lung Transplantation Guidelines for mechanical circulatory support: executive summary. J Heart Lung Transpl. 2013;32:157-87.

3. Kirklin JK, Pagani FD, Goldstein DJ, John R, Rojers JG, Atluri P, et al. American Association for Thoracic Surgery/International Society for Heart and Lung Transplantation guidelines on selected topics in mechanical circulatory support. J Heart Lung Transpl. 2020;39:187-219.

4. Noly PE, Pagani FD, Noiseux N, Stulak JM, Khalpey Z, Carrier M, et al. Continuous-flow left ventricular assist devices and valvular heart disease: a comprehensive review. Can J Cardiol. 2020;36:244-60.

5. Morgan JA, Brewer RJ, Nemeh HW, Murthy R, Williams CT, Lanfear DR, et al. Left ventricular reverse remodeling with a continuous flow left ventricular assist device measured by left ventricular end-diastolic dimensions and severity of mitral regurgitation. ASAIO J. 2012;58:574-7.

6. Kanwar MK, Rajagopal K, Itoh A, Silvestry SC, Uriel N, Cleveland JC, et al. Impact of left ventricular assist device implantation on mitral regurgitation: an analysis from the MOMENTUM 3 trial. J Heart Lung Transpl. 2020;39:529-37.

7. Wang TS, Hernandez AF, Felker GM, Milano CA, Rogers JG, Patel CB. Valvular heart disease in patients supported with left ventricular assist devices. Circ Heart Fail. 2014;7:215-22.

8. Stulak JM, Tchantchaleishvili V, Haglund NA, Davis ME, Schirger JA, Cowger JA, et al. Uncorrected pre-operative mitral valve regurgitation is not associated with adverse outcomes after continuous-flow left ventricular assist device implantation. J Heart Lung Transpl. 2015;34:718-23.

9. Robertson JO, Naftel DC, Myers SL, Tedford RJ, Joseph SM, Kirklin JK, et al. Concomitant mitral valve procedures in patients undergoing implantation of continuous-flow left ventricular assist devices: an INTERMACS database analysis. J Heart Lung Transpl. 2018;37:79-88. 
10. Taghavi S, Hamad E, Wilson L, Clark R, Jayarajan SN, Uriel N, et al. Mitral valve repair at the time of continuous-flow left ventricular assist device implantation confers meaningful decrement in pulmonary vascular resistance. ASAIO J. 2013;59:469-73.

11. Choi JH, Luc JGY, Moncho Escrivá E, Phan K, Rizvi SSA, Patel S, et al. Impact of concomitant mitral valve surgery with LVAD placement: systematic review and meta-analysis. Artif Organs. 2018;42:1139-47.

12. Kassis H, Cherukuri K, Agarwal R, Kanwar M, Elapavaluru S, Sokos GG, et al. Significance of residual mitral regurgitation after continuous flow left ventricular assist device implantation. JACC Heart Fail. 2017;5:81-8.

13. Sugiura T, Kurihara C, Kawabori M, Critsinelis AC, Wang S, Civitello AB, et al. Concomitant valve procedures in patients undergoing continuous-flow left ventricular assist device implantation: a single-center experience. J Thorac Cardiovasc Surg. 2019;158:1083-9.e1.

14. Tanaka A, Onsager D, Song T, Cozadd D, Kim G, Sarswat N, et al. Surgically corrected mitral regurgitation during left ventricular assist device implantation is associated with low recurrence rate and improved midterm survival. Ann Thorac Surg. 2017;103:725-33.

15. Tang PC, Haft JW, Romano MA, Bitar A, Hasan R, Palardy M, et al. Right ventricular function and residual mitral regurgitation after left ventricular assist device implantation determines the incidence of right heart failure. $J$ Thorac Cardiovasc Surg. 2020;159:897-905.e4.

16. John R, Mantz K, Eckman P, Rose A, May-Newman K. Aortic valve pathophysiology during left ventricular assist device support. J Heart Lung Transpl. 2010; 29:1321-9.

17. Tanaka Y, Nakajima T, Fischer I, Wan F, Kotkar K, Moon MR, et al. The impact of uncorrected mild aortic insufficiency at the time of left ventricular assist device implantation. J Thorac Cardiovasc Surg. 2020;160: 1490-500.e3.

18. Robertson JO, Naftel DC, Myers SL, Prasad S, Mertz GD, Itoh A, et al. Concomitant aortic valve procedures in patients undergoing implantation of continuousflow left ventricular assist devices: an INTERMACS database analysis. J Heart Lung Transpl. 2015;34:797-805.
19. Truby LK, Garan AR, Givens RC, Wayda B, Takeda K, Yuzefpolskaya M, et al Aortic insufficiency during contemporary left ventricular assist device support: analysis of the INTERMACS Registry. JACC Heart Fail. 2018;6:951-60.

20. Holley CT, Fitzpatrick M, Roy SS, Alraies MC, Cogswell R, Souslian L, et al Aortic insufficiency in continuous-flow left ventricular assist device support patients is common but does not impact long-term mortality. J Heart Lung Transpl. 2017;36:91-6.

21. Rajagopal K, Daneshmand MA, Patel CB, Ganapathi AM, Schechter MA, Rogers JG, et al. Natural history and clinical effect of aortic valve regurgitation after left ventricular assist device implantation. J Thorac Cardiovasc Surg. 2013; 145:1373-9.

22. Auvil B, Chung J, Ameer A, Han J, Helmers M, Birati E, et al. Moderate aortic insufficiency with a left ventricular assist device portends a worse long-term survival. ASAIO J. 2020;66:780-5.

23. Pawale A, Itagaki S, Parikh A, Pinney SP, Adams DH, Anyanwu AC. Mitral valve repair for severe mitral valve regurgitation during left ventricular assist device implantation. J Thorac Cardiovasc Surg. 2019;157:1841-8.e1.

24. McKellar SH, Deo S, Daly RC, Durham LA, Joyce LD, Stulak JM, et al. Durability of central aortic valve closure in patients with continuous flow left ventricular assist devices. J Thorac Cardiovasc Surg. 2014;147:344-8.

25. Fukuhara S, Takeda K, Chiuzan C, Han J, Kurlansky PA, Takayama H, et al Concomitant mitral repair and continuous-flow left ventricular assist devices: is it warranted? J Thorac Cardiovasc Surg. 2017;154:1303-12.e4.

26. John R, Naka Y, Park SJ, Sai-Sudhakar C, Salerno C, Sundareswaran KS, et al Impact of concurrent surgical valve procedures in patients receiving continuous-flow devices. J Thorac Cardiovasc Surg. 2014;147:581-9.

27. Fukuhara S, Ikegami H, Polanco AR, Song JJ, Han J, Takeda K, et al. Concomitant repair for mild aortic insufficiency and continuous-flow left ventricular assist devices. Eur J Cardiothorac Surg. 2017;52:1062-8.

Key Words: aortic insufficiency, aortic valve, mitral regurgitation, mitral valve, left ventricular assist device 